Firat University Journal of Experimental and
Computational Engineering
Firat Üniversitesi Deneysel ve Hesaplamalı
Mühendislik Dergisi

\title{
Using computational fluid dynamics for wave generation and evaluation of results in numerical wave tank modelling
}

\section{Sayısal dalga tankı benzetiminde dalga üretimi ve sonuçların değerlendirilmesi amacıyla hesaplamalı akışkanlar dinamiği kullanılması}

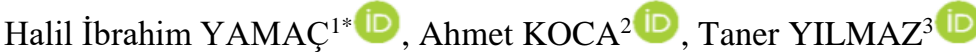 \\ ${ }^{1,2,3}$ Department of Mechatronics Engineering, Firat University, Elazığ, Turkey. \\ 1'halilymc@gmail.com, ${ }^{2}$ a.koca@ firat.edu.tr, ${ }^{3}$ t.yilmaz@ firat.edu.tr
}

\begin{abstract}
In this paper, computational modeling of wave generation and evaluation of results are given. The analysis of Computational Fluid Dynamics is performed in the ANSYS Fluent module. The model of numerical analysis is made time-dependent. The Numerical Wave Tank is an engineering research equipment for studying sea waves that requires the least amount of people and materials. The Numerical Wave Tank may be used to simulate the motion of the ocean and sea waves with a modeled moving wall as a wave-maker. To generate regular gravity waves, a Numerical Wave Tank based on Reynolds Averaged Navier Stokes equations and the Volume of Fluid technique is modeled using Dynamic Mesh Technique. Wave heights, water depths, wavelength and wave periods are chosen variable parameters. Water volume fraction, velocities, turbulence kinetic energy and dynamic pressure are evaluated results. A brief explanation of how to generate waves influence is made.
\end{abstract}

Keywords: Computational fluid dynamics, Volume of fluid method, Numerical wave tank, Dynamic mesh technique, User defined function

\section{Özet}

$\mathrm{Bu}$ makalede, dalga üretiminin hesaplamalı modellemesi ve sonuçların değerlendirilmesi verilmektedir. Hesaplamalı Akışkanlar Dinamiğinin analizi ANSYS Fluent modülünde gerçekleştirilir. Sayısal analiz modeli zamana bağlı yapılmıştır. Sayısal Dalga Tankı, deniz dalgası konusunda en az insan gücü ve malzeme kaynağı gerektiren mühendislik araştırma aracı olarak düşünülebilir. Sayısal Dalga Tankı, dalga yapıcı olarak hareketli duvar modelleme ile okyanus ve deniz dalgalarının hareketini simüle etmek için kullanılabilir. Reynolds-Ortalamalı Navier-Stokes denklemlerine ve Akışkan Hacmi yöntemine dayalı Sayısal Dalga Tankı, düzenli yerçekimi dalgaları oluşturmak için Dinamik Ağ Tekniği kullanılarak modellenmiştir. Dalga yükseklikleri, su derinlikleri, dalga boyu ve dalga periyotları değişken parametreler olarak seçilmiştir. Su hacim oranı, hızlar, türbülans kinetik enerjisi ve dinamik basınç sonuçları değerlendirilmiştir.

Anahtar kelimeler: Hesaplamalı akışkanlar dinamiği, Akışkan hacmi yöntemi, Sayısal dalga tankı, Dinamik ağ tekniği, Kullanıcı tanımlı fonksiyon

\section{Introduction}

Renewable energy systems are sustainable by means of energy production. It can be said that they have huge potential. It is an undeniable fact that waves are potential energy source. Many studies and designs have been done on energy generating systems in the ocean and sea. These studies are about energy generation, designing breakwaters or floating behavior of ships. There are many studies on Numerical Wave Tanks (NWT). Waves on the sea surface are periodical water movements. Waves have mixed random properties. Large amounts of energy can be transformed into electrical power via wave motions [1]. Fluid behavior due to wave breakers in a non-hydrostatic system and the effect of the fluid on wave breakers can be investigated numerically. Changes in the wave profile can be observed due to wave breaks [2]. In the work done by Finnegan and Goggins, ocean waves are modeled on a NWT to study fluid / solid interactions. The wave energy conversion system has been studied for a floating body. When comparing analytical studies with numerical

${ }^{*}$ Corresponding author 
simulations, water particle movements are evaluated depending on the time. The model has been achieved with better results for high-amplitude and low-frequency waves [3]. Bhinder et al. discover the forces of fluid impact on the production of power in wave energy converting systems with using Computational Fluid Dynamics (CFD) simulations. System efficiency as a function of time is investigated in relation to the forces acting in the fluid environment. Waves having the desired property can be created using simulations. [4]. In the examination of fluid-solid interactions, Hu et al. 2016 use CFD for modeling waves to see how forces behave with structures that have variable shapes [5]. Liaghat discusses the analyses of the force interaction by means of fluid-solid and makes simulations on the fluid-based force effect of the solid structure of materials in his master's thesis. The convergence of waves with a solid body is the result of the momentum water effect on solid movements that are transferred to the surface of the final solids. In order to observe the interaction numerically, it is first necessary to create waves. The NWT simulations are made with different assumptions in CFD programs. Waves with certain qualities can be created using simulations [6]. In a study by Liu et al., a numerical simulation with Reynolds-Averaged-Navier-Stokes (RANS) equation is done for two-dimensional NWT modeling utilizing the Volume of Fluid (VOF) approach[7]. In the study by Wang and Liu, time-dependent wave generation is performed and the time-dependent change of the surface height parameter is obtained [8]. In the study performed by Zhu et al., RANS equations are used in the NWT model. It is also defined that momentum sources can be added to the CFD program using User Defined Functions (UDF) to create different regions. NWT is divided into regions where the waves have optimal modes such as wave generator wave formation and wave damping [9]. In a study by Oijeh et al., A kinematic study of extreme wave models is performed using RANS equations and VOF simulations. The highest (extreme) waves observed on the sea surface are examined [10]. Liang et al. said that extreme waves to be generated in the NWT are modeled. It is found that the variable properties of the generated non-uniform waves are appropriate. The horizontal velocities were obtained from the numerical and experimental results [11]. In this study, a two-dimensional (2D) NWT model is created. $\mathrm{UDF}$ is used to simulate waves in the $2 \mathrm{D}$ environment. How to generate waves, how the results are obtained from the simulation environment are explained briefly.

\section{Materials and Method}

The Fluent Module is used to generate waves in this investigation. The gravitational waves that occur on a regular basis are modeled. The waves have a sinusoidal shape, and their behavior does not alter at each time step. When an object is tossed into a tank of water, it causes irregularity and surface waves. The alignment of the water to its initial state as a result of gravity's acceleration causes the movements on the water's surface. Gusts can even be blamed for causing free surface waves. The wavelength equation is shown in Equation 1:

$$
L=\frac{g T^{2}}{2 \pi} \tanh \left(\frac{2 \pi h}{L}\right)
$$

Where the depth of water is $\mathrm{h}$, the length of the wave is $\mathrm{L}$, the acceleration of gravity is $\mathrm{g}$, the period of the wave is $\mathrm{T}$. The time it takes for a wave to form is known as its period. The amount of time it takes for a length of a wave to form. Depending on the linear or nonlinear parameters, wave generation varies according to boundary conditions and physical realities [12]. Free surface dynamic, surface and bottom conditions can be called boundary conditions of gravitational waves.

\subsection{Governing Equations}

The solver in Fluent uses the finite volume methodology as its foundation. The governing equations are discretized and solved repeatedly across each sub-region using this technique, which separates the region of interest into sub-regions. As a result, the value of each variable's approximation at places in the domain is attained. In the Fluent module, the Pressure Implicit with Splitting of Operator (PISO) Solver is employed. The pressure-velocity connection diagram is part of the SIMPLE algorithm family, which relies on a high degree of approximation of the relationship between pressure and velocity. The limitation of the SIMPLE and SIMPLEC algorithms is that they do not provide the momentum balance of the new velocity and approximate flow values after the pressure verification equation is solved. As a result, the solution should be repeated until equilibrium is achieved. The PISO algorithm uses two extra corrections to increase the effectiveness of this calculation. Adjoining correction and asymmetry correction are two of them. The Navier-Stokes 
equations are applied directly to the system by the SIMPLE and SIMPLEC algorithms, with the parameters added after the user selects them [13]. The equations of continuity of mass and Navier Stokes are [14]:

$$
\frac{\partial \rho}{\partial t}+\frac{\partial(\rho u)}{\partial x}+\frac{\partial(\rho w)}{\partial z}=0
$$

$\rho\left(\frac{\partial u}{\partial t}+u \frac{\partial u}{\partial x}+w \frac{\partial u}{\partial z}\right)=-\frac{\partial p}{\partial x}+2 \mu \frac{\partial^{2} u}{\partial x^{2}}+\frac{\partial}{\partial z}\left(\mu\left(\frac{\partial u}{\partial z}+\frac{\partial w}{\partial x}\right)\right)+F_{x}$

$$
\rho\left(\frac{\partial w}{\partial t}+u \frac{\partial w}{d x}+w \frac{\partial w}{\partial z}\right)=-\frac{\partial p}{\partial z}+2 \mu \frac{\partial^{2} w}{\partial z^{2}}+\frac{\partial}{\partial x}\left(\mu\left(\frac{\partial u}{\partial z}+\frac{\partial w}{\partial x}\right)\right)-\rho g+F_{z}
$$

for the 2D NWT, the $x$ and $y$ are coordinate system positions, the fluid density of the fluid is $\rho$, the pressure is $p$, the velocity in the horizontal direction is $u$, the velocity in the vertical direction is $v$, time is $t$, the viscosity is $\mu$. The dynamic pressure values are calculated from the solver by using formulation $V$ is velocity magnitude, Equation 5 shows the Dynamic pressure [13]:

$$
P_{d}=\frac{\rho_{m}-\rho_{o}}{2} V^{2}
$$

\subsection{Numerical wave tank}

Fluent was used to simulate 2D NWT. If it is not intended to obtain side effects, the difference between 2D and 3D analysis results can be considered the same. Because the average variables on lines in $2 \mathrm{D}$ are the same with the average variables on areas in 3D. When 3D modelling is made, Data are reviewed and plotted on a plane parallel to the wave motion.

In this study, when waves are generated in the NWT, a piston wavemaker is used. The tank's left wall acts as a wave generator. The UDF is used to move the wall on a regular basis. During the investigation, transient analysis is employed. PISO algorithm is used as solver with k-epsilon (k- $\varepsilon$ ) Turbulence Model, Realizable Wall Functions, Pressure Based VOF model. Dynamic Mesh settings is used. The NWT is shown in Figure 1.

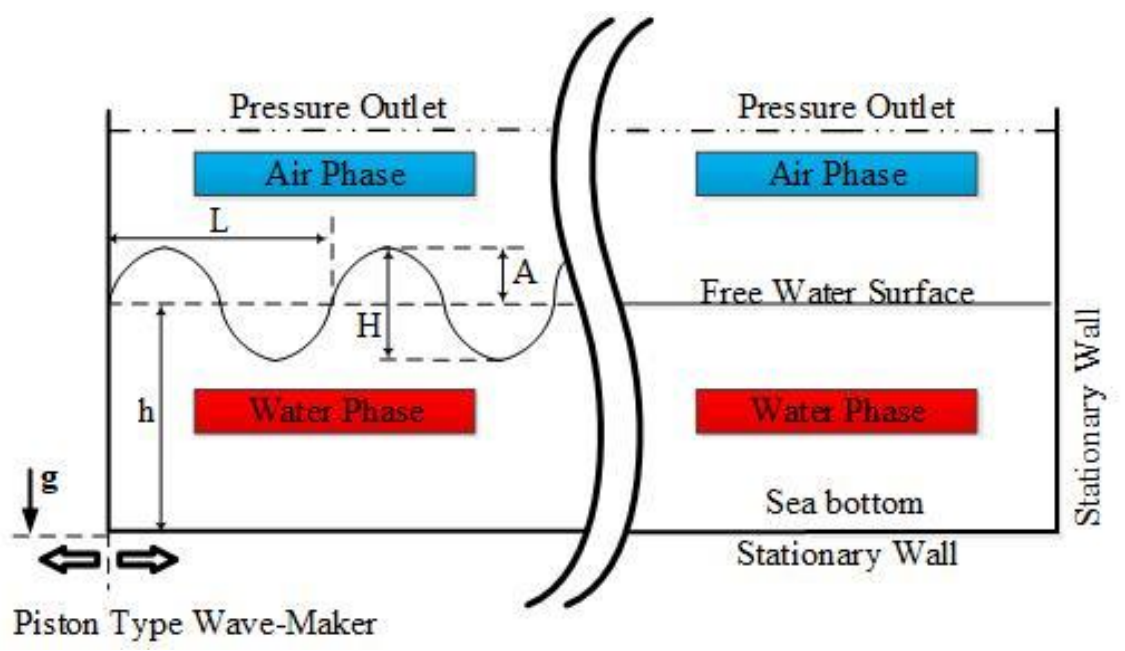

Figure 1. Numerical wave tank

The NWT simulation is done with a tank that is 200 meters long. The differences between the examples in this study are the initial depth of water and wave height. The fluent module employs the VOF approach. This approach is frequently 
utilized in the Fluent module's time-dependent solutions. Multiple immiscible fluids are modeled using the VOF approach. The volume fraction parameter is used in the VOF method formulation to model a mixture of two or more phases. There are two phases in the simulation, which are air and water. In Table 1, the qualities of phases are listed.

Table 1. Material properties used in fluent

\begin{tabular}{lll}
\hline Name of Material & Density & Viscosity \\
\hline Air & $1.225 \mathrm{~kg} / \mathrm{m}^{3}$ & $1.7894 \times 10^{-5} \mathrm{~kg} / \mathrm{ms}$ \\
Water-liquid & $998.2 \mathrm{~kg} / \mathrm{m}^{3}$ & $0.001003 \mathrm{~kg} / \mathrm{ms}$ \\
\hline
\end{tabular}

The volume fraction in the computed cells is defined as a variable for each phase contributed to the model. At each control volume, the volume fractions are combined. For all variables and characteristics, fields by phase and average volume values are shared. For each phase, the volume fraction values of each zone are determined in separate regions. The features and variables in the cells are represented as one of the phases or a mixture in the cells. ${ }^{\alpha}{ }_{q}$ can be used to represent a volume fraction. There are three scenarios in which ${ }^{\alpha_{q}}[13]$ :

-if $\alpha_{q}=0$, then cell q ( $\left.\mathrm{q}=1,2,3 \ldots\right)$ is empty for numbering fluids.

$\cdot$ if $\alpha_{q}=1$, then cell $\mathrm{q}(\mathrm{q}=1,2,3 \ldots)$ is full for numbering fluids.

-if $0<\alpha_{q}<1$, then cell q ( $\left.\mathrm{q}=1,2,3 \ldots\right)$ have phases of more than one in the cell.

$\alpha_{q}$ using regional values, each control volume in the relevant area is given the required variables and attributes.

$\frac{1}{\rho_{q}}\left[\frac{\partial}{\partial_{t}}\left(\rho_{q} \alpha_{q}\right)+\nabla\left(\rho_{q} \alpha_{q} \overrightarrow{v_{q}}\right)\right]=S_{\alpha_{q}}+\sum_{p=1}^{n}\left(\dot{m}_{r q}-\dot{m}_{q r}\right)$

where, the mass transfer (instantaneous) from q phase to r phase is $\dot{m}_{q r}$, the mass transfer (instantaneous) from r phase to q phase is $\dot{\bar{m}}_{r q}$, for initial conditions $S_{\alpha_{q}}$ is zero, also with UDF, $S_{\alpha_{q}}$ is added in Equation 6. The equation of momentum is:

$\frac{\partial}{\partial t}(\rho \overrightarrow{\rho v})+\nabla(\overrightarrow{\rho v v})=-\nabla P+\nabla \cdot\left[\mu\left(\nabla \vec{v}+\nabla \overrightarrow{v^{T}}\right)\right]+\rho \vec{g}+\vec{F}$

where, the static pressure is $P, \vec{F}$ is added force, the gravitational force is $\rho \vec{g}, \mu$ is viscosity. When simulating wave production, a piston type wave generator is employed. The properties of the waves are determined by the left wall motion function. The displacement of piston is calculated with $h$ (water depth), $S$ (piston displacement), $H$ (wave height), $k=2 \pi$ $/ L$ (wave number). The piston displacement equation is [15]:

$\left(\frac{H}{S}\right)_{\text {piston }}=\frac{2(\cosh (2 k h)-1)}{\sinh (2 k h) 2 k h}$

Because the equation is time dependent, any wave elevation must be represented in terms of the piston's motion. When the maximum wave height value is taken as the $A$ value for wave amplitude, the $S$ displacement of the piston can be represented as maximum $S_{0}$. Piston displacement owing to wave period equation [16]: 
$X(t)=\frac{S_{0}}{2}\left(1-e^{-\frac{5 t}{2 T}}\right) \sin (\omega t)$

The derivative of Equation 9 is the wall velocity depend on time. Equation 10 is used while the preparation of UDF. Equation 10 is [17]:

$$
V(t)=\left(\frac{s_{0}}{2}\right)\left(1-e^{-\frac{5 t}{2 T}}\right) \omega \cos (\omega t)+\frac{5}{2 T} e^{-\frac{5 t}{2 T}} \sin (w t)
$$

\subsection{Fluent setup selection}

The aim of this paper briefly explains the NWT analysis, so the user interface options of the CFD program Fluid Flow (Fluent) module are defined in Table 2 and Table 3. Before running the calculation, the selection of "Adapt $>$ Region" is done. In this selection air and water volumes are defined by using the "Mark" button after initialization of the solution. Then "Patch..." button is used for defining the water phase (phase-2 must be chosen under the "Phase" heading) Volume Fraction Value. If the defined volume which is chosen under the heading "Register to Patch" is assumed full with air the value under heading "Value" is 0 . When defining water volume this value of volume fraction becomes 1 . After this procedure patch button is used to close the window. All the options are settled as shown in Table 2 and Table 3 before running the calculation.

Table 2. Solution setup in fluent flow (fluent) setup section

\begin{tabular}{|c|c|c|}
\hline \multicolumn{3}{|l|}{ Solution Setup } \\
\hline \multirow[t]{2}{*}{ General } & Solver & $\begin{array}{l}\text { Type > Pressure-Based } \\
\text { Velocity Formulation }>\text { Absolute } \\
\text { Time > Transient } \\
2 D \text { Space > Planar }\end{array}$ \\
\hline & Gravity & $Z(\mathrm{~m} / \mathrm{s})=-9.81$ \\
\hline Models & \multicolumn{2}{|c|}{$\begin{array}{l}\text { Multiphase - Volume of Fluid } \\
\text { Viscous - Realizable k-e, Scalable Wall Fn }\end{array}$} \\
\hline Materials & Fluid & $\begin{array}{l}\text { water-liquid } \\
\text { air }\end{array}$ \\
\hline Phases & \multicolumn{2}{|c|}{ Phase 1 (air), Phase 2 (water-liquid) } \\
\hline Cell Conditions & \multicolumn{2}{|c|}{ Zone (surface_body), mixture, fluid } \\
\hline $\begin{array}{l}\text { Boundary } \\
\text { Conditions }\end{array}$ & \multicolumn{2}{|c|}{ Left, right and bottom lines $=$ wall , top line $=$ pressure -outlet } \\
\hline Dynamic Mesh & Layering & Dynamic Mesh Zones > Left wall - Rigid Body \\
\hline
\end{tabular}

Table 3. Solution in fluent flow (fluent) setup section

\begin{tabular}{|c|c|c|}
\hline \multicolumn{3}{|l|}{ Solution } \\
\hline Solution Method & PISO & $\begin{array}{l}\text { Gradient = Least Square Cell Based } \\
\text { Pressure = PRESTO! } \\
\text { Volume Fraction = Geo-Reconstruct } \\
\text { Other options = Second Order Upwind }\end{array}$ \\
\hline Solution Initialization & Hybrid & (Adapt phases then) Patch... (Regions) \\
\hline Calculation Activities & $\begin{array}{l}\text { Automatic } \\
\text { Export }\end{array}$ & CFD-Post Compatible \\
\hline Run Calculation & $\begin{array}{l}\text { Time Step } \\
\text { Max Iterati }\end{array}$ & $\begin{array}{l}\mathrm{ze}(\mathrm{s})<=0.005 \\
\mathrm{ls} / \text { Time Step }=>45\end{array}$ \\
\hline
\end{tabular}




\subsection{User defined function}

The UDF is written in the $\mathrm{C}$ programming language and introduced in the Fluent module of the program. The dynamic variables in the system are defined in the program to obtain the wave.

The first UDF code must be defined in the Fluent Setup section. The buttons used for this operation is "Define $>$ UserDefined $>$ Functions $>$ Complied..." and then Source Files "Add..." button is used to add the file of c code, Header Files "Add..." button is used to add libraries "udf.h" and "dynamesh tools.h" which are in the folder of Fluent $>$ libudf $>$ src. The header libraries are written in beginning of $\mathrm{C}$ code with first line "\#include "udf.h" " and second line "\#include "dynamesh_tools.h" ".

The third line of the code is header as "DEFINE_CG_MOTION(wave,dt,vel,omega,time,dtime)". The variables used in code must be defined in brackets near of header. The function code is " $4\{$ Thread *t; 5 face $t \mathrm{f} ; 6 \mathrm{t}=\mathrm{DT}$ THREAD $(\mathrm{dt})$; 7 float T,S; 8begin f_loop $(\mathrm{f}, \mathrm{t}) 9\left\{\operatorname{vel}[0]=\ldots\right.$ end $\left.\mathrm{f} \_\operatorname{loop}(\mathrm{f}, \mathrm{t})\right\}$ ". T is period of wave and $\mathrm{S}$ is displacement of wall in the code. "vel $[0]=\ldots$.. is the velocity in the $\mathrm{x}$ direction of wave maker which can be seen in Equation 9. When code is written, the assumption of is made in programming.

In Fluent Setup Section, the dynamic mesh structure used during wave generation is chosen as "Layering". "Dynamic Mesh > Create/Edit..." button is used to select left wall as "Dynamic Mesh Zone". The function which is compiled is chosen under the header option of "Motion/UDF Profile" is chosen motion as "Rigid Body". The object is separated into small squares in this mesh structure. Each square is separated by $0.1 \mathrm{~m}$ on one side. These sections can be separated from one another within the mesh framework. On moving mesh structures, the program is used to solve the effects of gravity on water particles.

\section{Results}

When analyses are performed, the geometry of the NWT is not changed. The heights of the generated wave, wave period, height and depth of water in various different situations are compared with each other by varying results. Wave characteristics and positioning of the conditions are shown in Table 4.

While the instances are being determined and simulated, the NWT is 200 meters long. The results are reviewed once comparisons are made between the cases. In some circumstances, the wave velocity varies.

Table 4. Cases and parameters

\begin{tabular}{|c|c|c|c|c|c|}
\hline & $\begin{array}{l}\text { Wave } \\
\mathrm{H}(\mathrm{m})\end{array}$ & Height & $\begin{array}{l}\text { Water Depth } \\
h(\mathrm{~m})\end{array}$ & $\begin{array}{l}\text { Wave Length } \\
\mathrm{L}(\mathrm{m})\end{array}$ & $\begin{array}{l}\text { Wave Period } \\
\mathrm{T}(\mathrm{s})\end{array}$ \\
\hline Case 1 & 1 & & 16 & 53.6 & 6 \\
\hline Case 2 & 2 & & 16 & 53.6 & 6 \\
\hline Case 3 & 2 & & 28 & 56 & 6 \\
\hline Case 4 & 2 & & 16 & 25 & 4 \\
\hline Case 5 & 2 & & 5.11 & 53.6 & 8 \\
\hline
\end{tabular}

\subsection{Validation}

Numerical studies' dependability is determined by comparing them to experimental, analytical, or other results published in the literature. In the aforementioned work, an NWT simulation with a water depth of $16 \mathrm{~m}$ at the start and a tank length of $200 \mathrm{~m}$ was employed for validation. A-line 20 meters from the NWT's left edge is used for sampling. The value of the water depth variable on a line can be obtained from the Fluent Results Section. An expression is defined in the Results section. For example if "Line 1" is the name of the line from which the water height results are obtained and "Phase 2" is 
the volume fraction of water, the expression for water depth variable becomes "lengthInt(Phase 2.Volume Fraction)@Line 1 ". The chart of expression versus time gives the transient water depth values on a line.

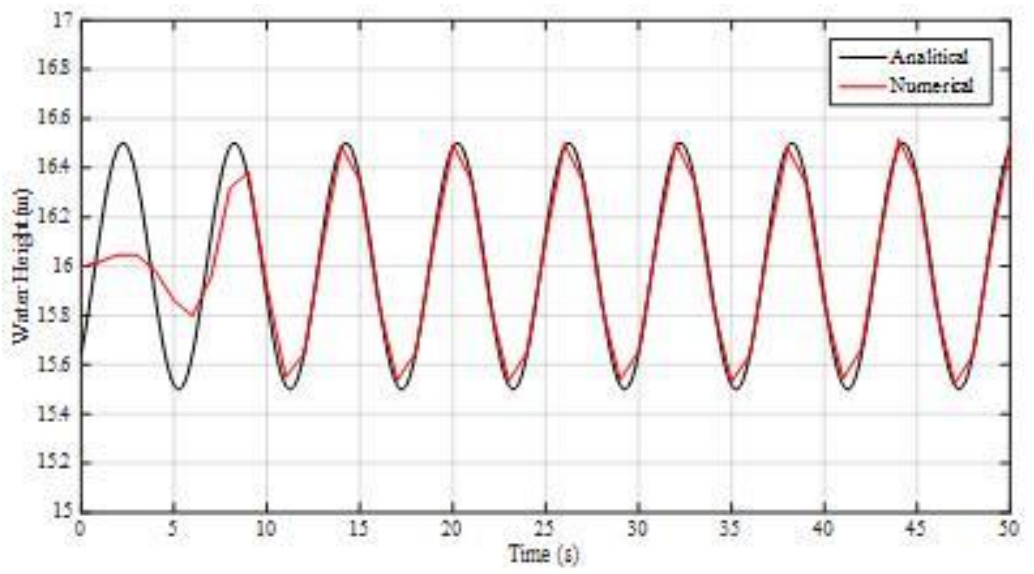

(a)

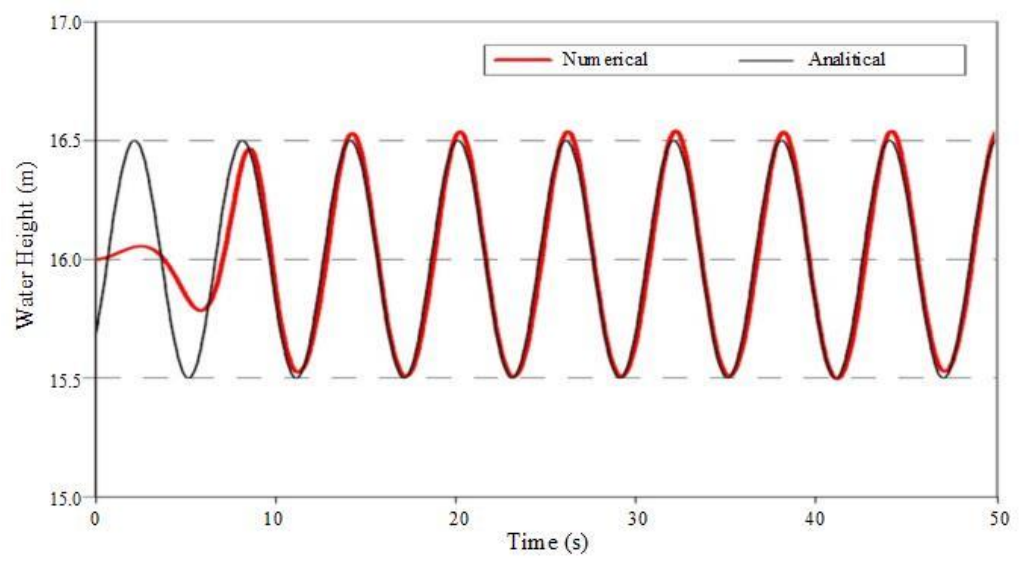

(b)

Figure 2. Validations (a) this study (b) study of gomes et al. [18].

A water surface level change vs. time chart is given. The created wave has a period of 6 seconds and a height of 1 meter. In Figure 2b, the study by Gomes et al. [18] is used for validation, in this work, Figure 2a depicts an analytical and numerical (time-dependent) water-time chart of water height. This analytical value is calculated from the basic sinusoidal wave equation. Wave height versus time charts can be seen in Figure 2.

\subsection{Wave generation results}

The movement of gas and liquid phases depends on time can be seen in Figure 3. The red component represents water with a volume fraction of 1 , the blue part represents air with a volume fraction of 0 , and there is an isosurface line connecting the two parts. The isosurface volume fraction is approved at 0.5 . The color difference between portions indicates that the mesh structure contains a mixture of water and air. The variability of the volume fraction from 0 to 1 can be seen using contours. The tank's right wall is considered to be fixed. There's no such thing as a damping function or a porous structure. Because the right wall of the pool lacks a dampening function, the length of the pool is significantly more than the depth of the water, preventing errors near the left wall. This decreases the likelihood of measurement errors near the left wall. Figure 3 shows waves with identical amplitudes are formed at areas near of left wall of the NWT. 


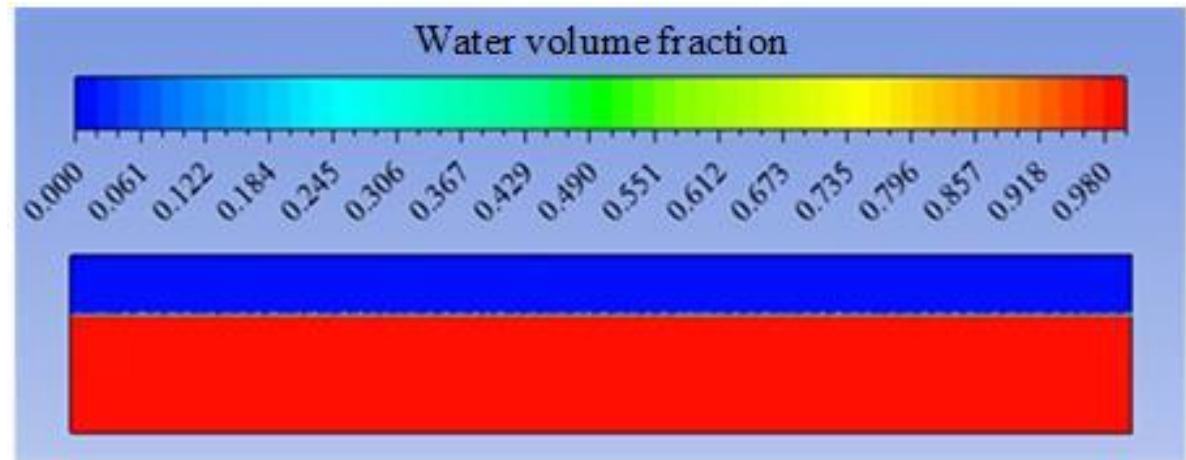

(a)

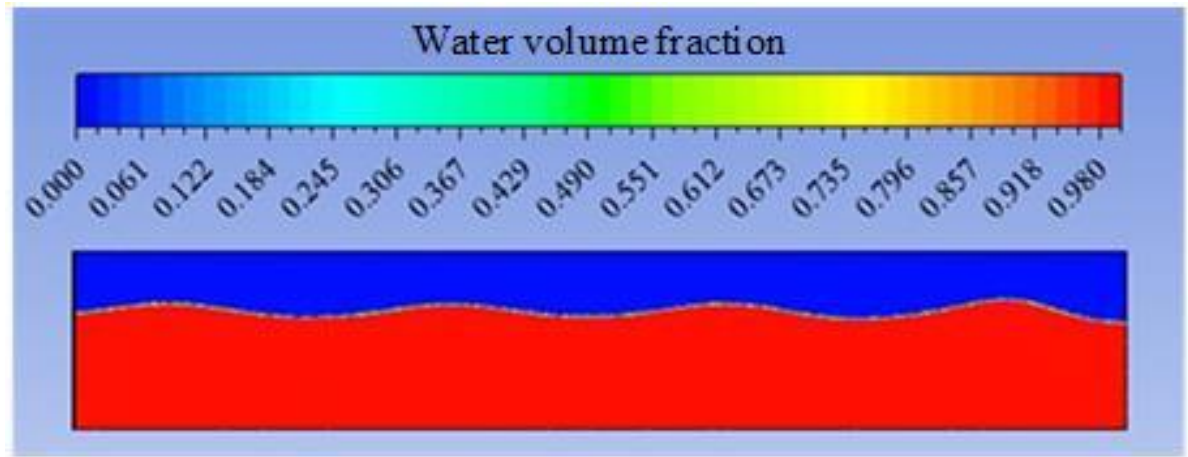

(b)

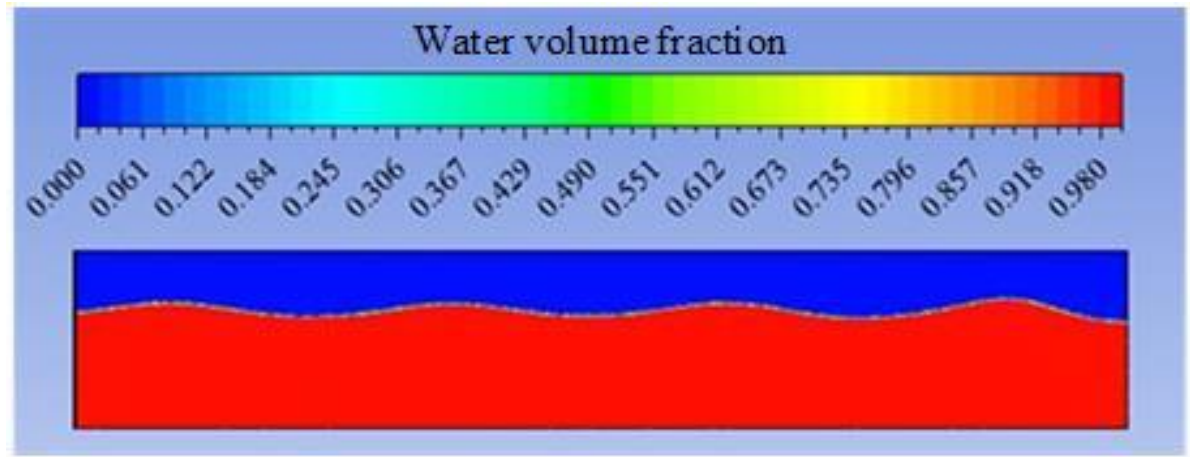

(c)

Figure 3. Water volume fractions in case 2 as represent all Cases (a) $t=0 \mathrm{~s}$ (b) $t=25 \mathrm{~s}$ (c) $\mathrm{t}=50 \mathrm{~s}$

Figure 4 shows the velocities in the $\mathrm{x}$-direction for the second case. At the start, all of the velocities are 0 . In the transient solution, the velocities indicate differences by time up to the end of the tank. The negative velocities are caused by the left wall's negative $\mathrm{x}$-direction movement, which is influenced by UDF. Wave theory works best with negative velocities. Negative velocities in the $\mathrm{x}$-direction related to dynamic water surface boundary conditions are caused by the elliptical motion of water particles. As it approaches wave trough, the negative $\mathrm{x}$ velocity increases, while the positive $\mathrm{x}$ velocity increases. 


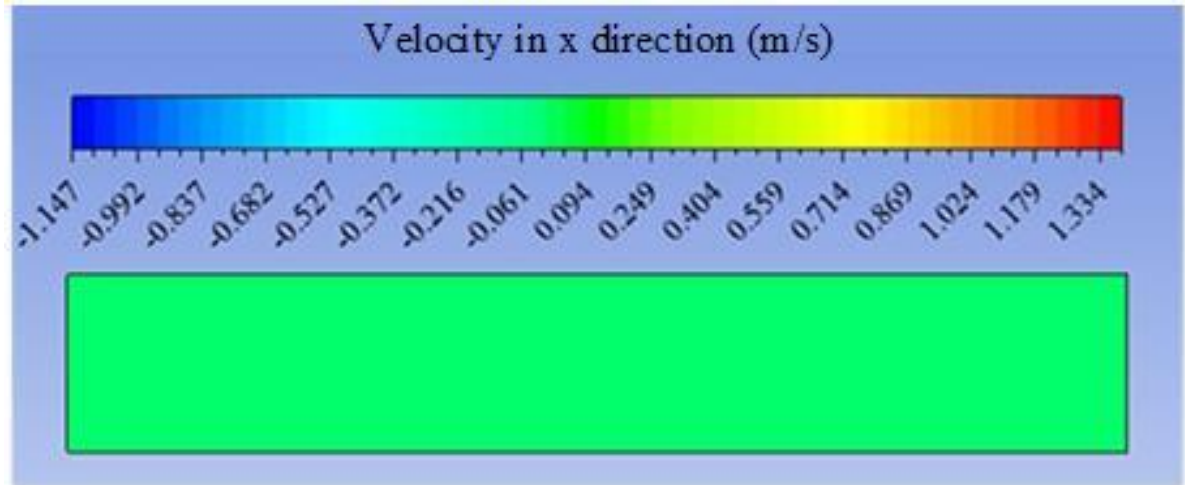

(a)

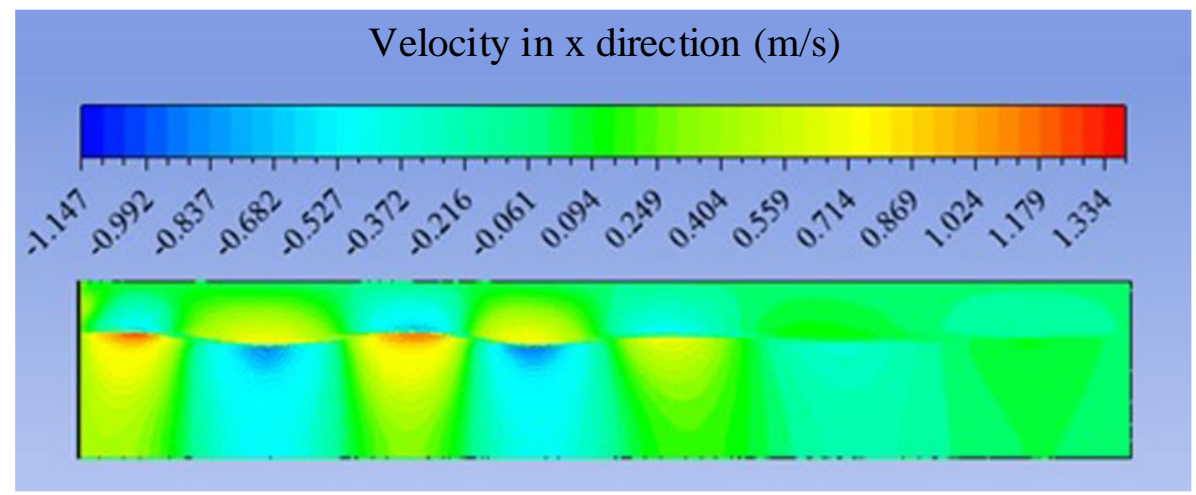

(b)

Figure 4. $u$ velocity in second case of numerical wave tank (a) $t=0 \mathrm{~s}$ (b) $t=25 \mathrm{~s}$

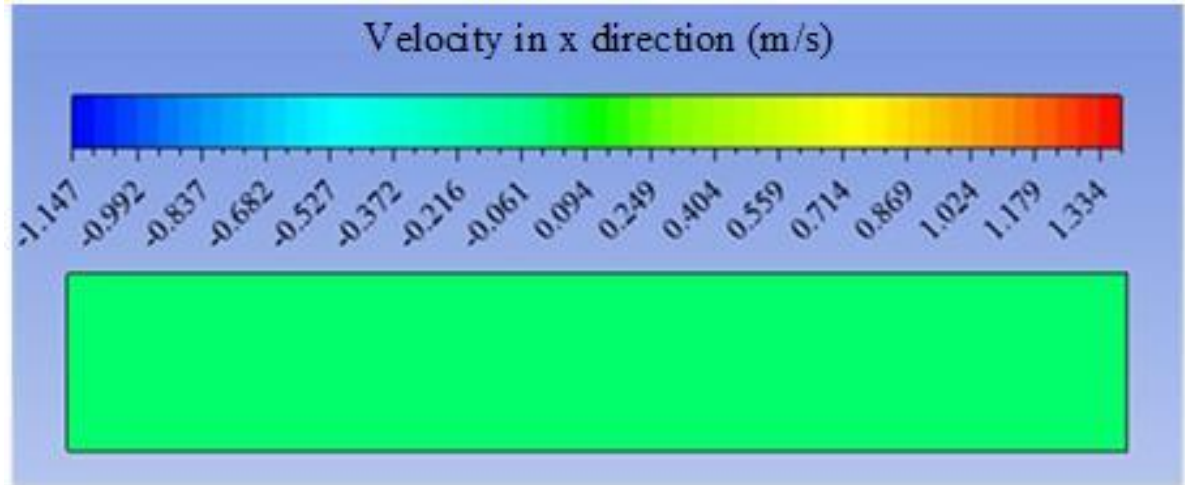

(a)

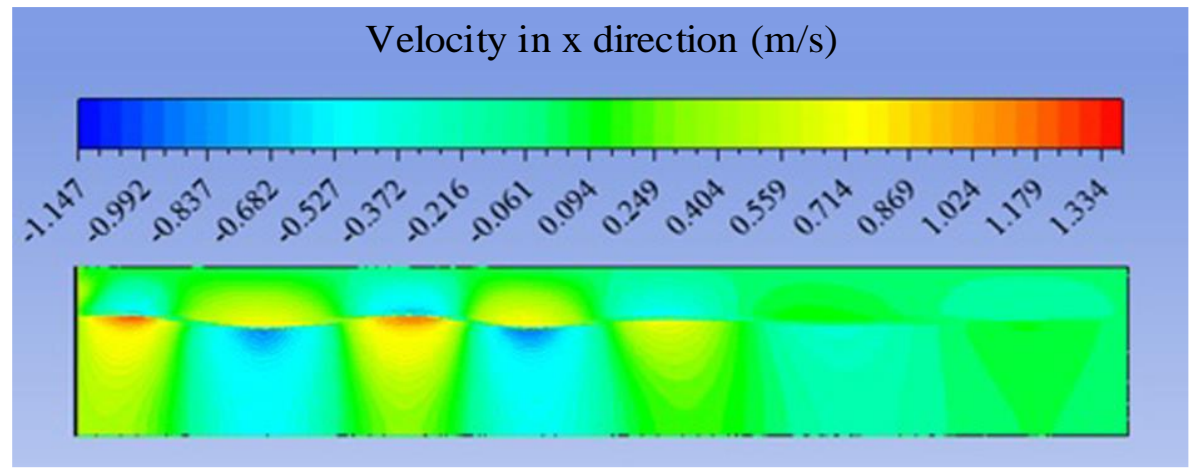

(b)

Figure 5. $v$ velocity in second case of numerical wave tank (a) $t=0 \mathrm{~s}$ (b) $\mathrm{t}=25 \mathrm{~s}$ 
Figure 5 shows the velocities in y-direction for the second case representing all of the cases in the numerical study. The variable values of $u$ velocities cause differences in pressure and momentum forces based on Navier-Stokes Equations. At the crests and troughs of waves, pressure fluctuations are greatest.

Figure 6 shows the dynamic pressure values in the NWT. Dynamic pressure values are directly related to velocities. For Case 1 the wave height is $1 \mathrm{~m}$, while for Case 2 it is $2 \mathrm{~m}$. As a result, the dynamic pressure value reaches values close to 4 times of Case 1 in Case 2.

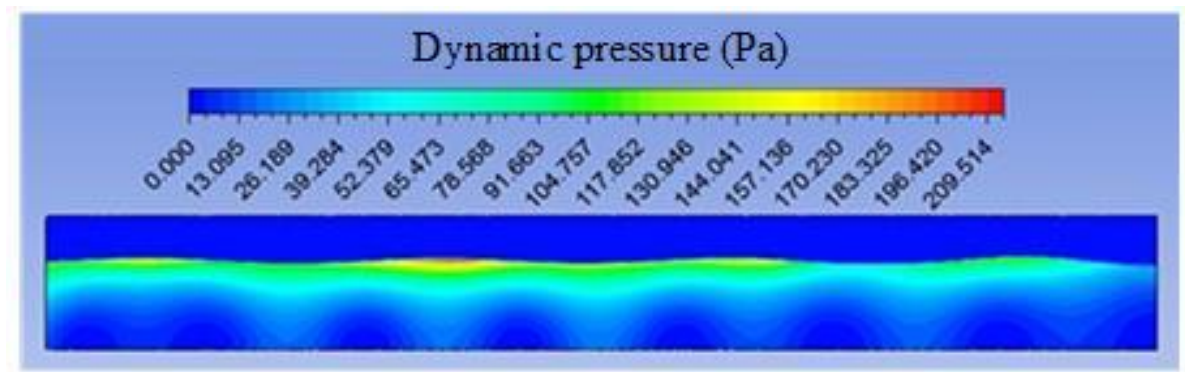

(a)

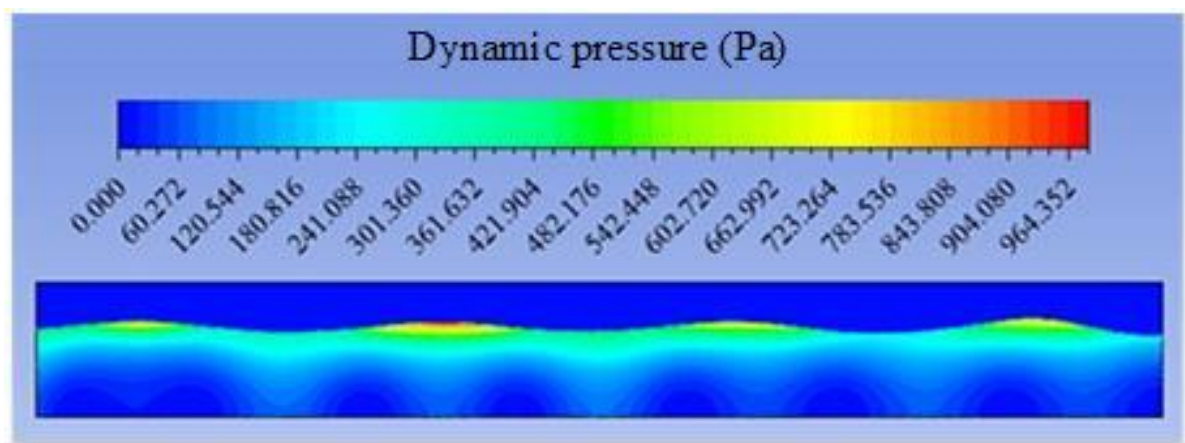

(b)

Figure 6. Dynamic pressures of time $=30 \mathrm{~s}$ (a) first case (b) second case

The comparison of Case 1 and Case 2 for observing the differences in results due to wave elevation also has implications for other cases. Figure 7 shows turbulent kinetic energy values. For Case 2, these values are several times higher than Case 1. This result also indicates that the amount of energy to be produced is excessive. Because, in principle, electric energy is the transformed state of the kinetic energy of the waves. Kinetic energy has higher values due to higher wave height. As the water particle movement decreases towards the depth of the water, the highest kinetic energy values are approached in the wave forming regions. Kinetic energy formation is also observed in the gas phase due to the liquid phase movement. Since the contours contain the mass ratio of the kinetic energy, the colors above and below the droplet are the same, but the kinetic energy of the liquid phase is considerably higher than that of the gas phase. 


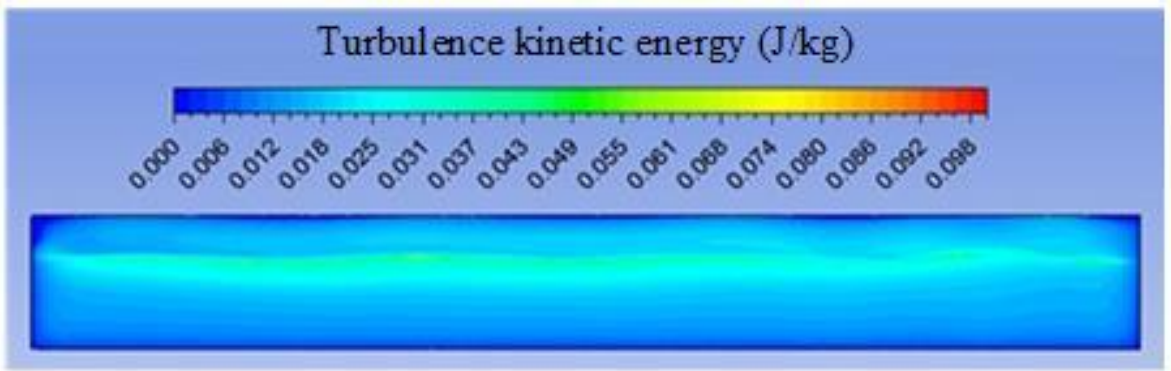

(a)

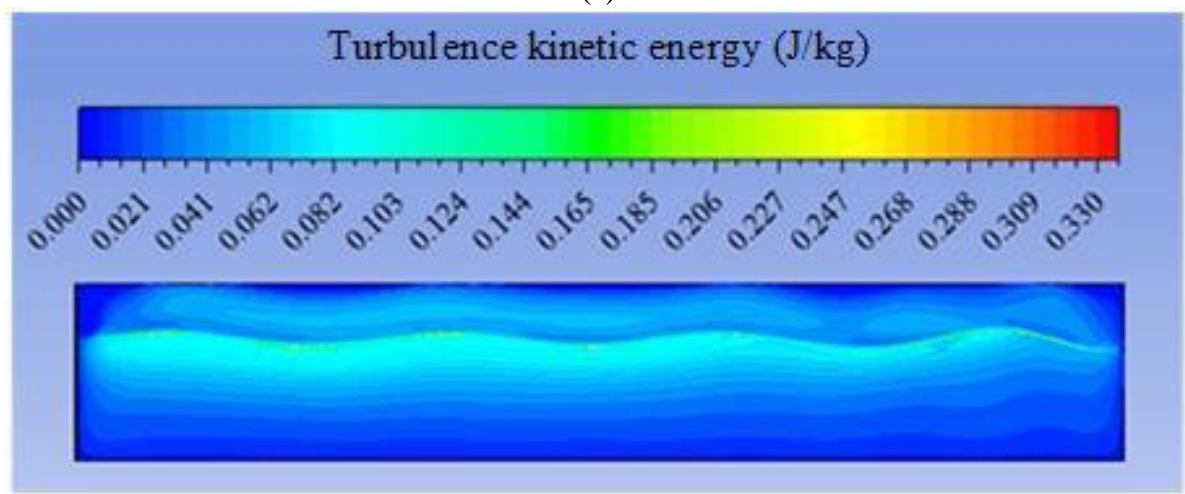

(b)

Figure 7. The turbulent kinetic energy of time $=30 \mathrm{~s}$ (a) first case (b) second case

The absolute pressure value of Case 4 is shown in Figure 8. Determining the pressure output shows the correctness of the simulated case where the area is colored equal to the open-air pressure.

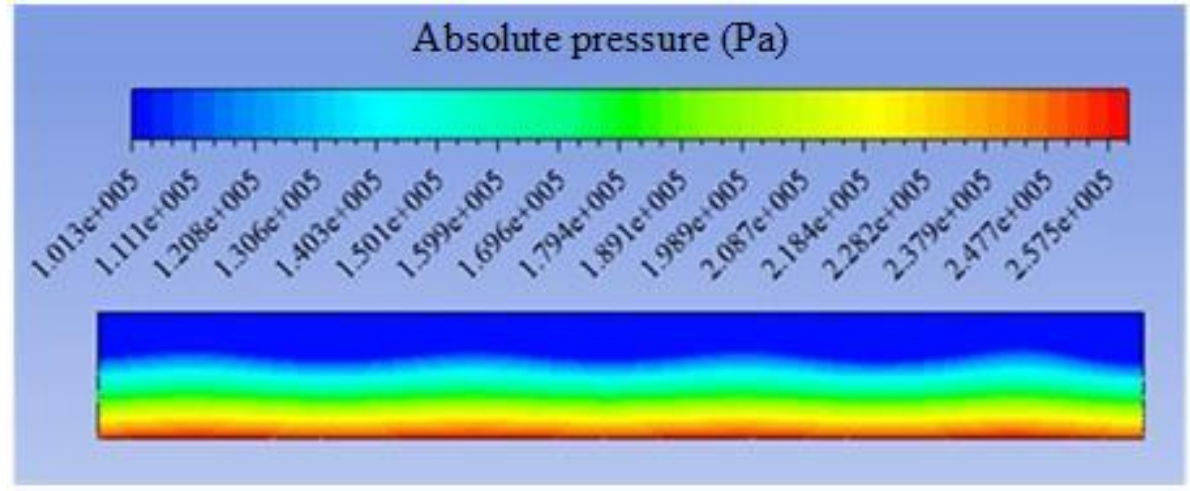

Figure 8. Absolute pressure at $\mathrm{t}=50 \mathrm{~s}$ in case 4

All results and figures are evidence of the movement in the NWT. The results can be used in calculations of the effect of the waves on solids or energy converters.

\section{Conclusion}

In the study, NWT simulations are carried out and the determining characteristics are modeled with time-dependent waves. The numerical study's findings are compared to the analytical findings. The NWT simulations were generated with the methods used to give appropriate results for gravity waves. Since the water depth wavelength ratio affects the results, this should be taken into account during the simulation work. The volume fraction, velocity profiles and pressure values can be clearly observed in the 2D NWT. The processes during generating waves are explained briefly. 
NWT studies form the basis for further studies to determine the effect of the fluid on the solid surface in the future. Wave energy conversion systems with stationary, floating or moving systems to be defined in the fluid, behavior analysis of floating objects, the effect of fluid movement in the water can be examined. As a result, it is expected that this work will generate new work and can be utilized as a source for studies on the subject.

\section{Author Contribution Statement}

In the study, Author 1 contributed to the analysis of the results, provision of the materials and examination of the results; Author 2 contributed to forming the idea, making the design and literature review; Author 3 contributed to checking the spelling and checking the article in terms of content.

\section{Ethics Committee Approval and Conflict of Interest}

There is no need for an ethics committee approval in the prepared article. There is no conflict of interest with any person/institution in the prepared article.

\section{References}

[1] Agamloh EB, Wallace AK, von Jouanne A. "Application of fluid-structure interaction simulation of an ocean wave energy extraction device". Renewable Energy, 33(4), 748-757, 2008.

[2] Liang B, Wu G, Liu F, Fan H, Li H. "Numerical study of wave transmission over double submerged breakwaters using non-hydrostatic wave model". Oceanologia, 57(4), 308-317, 2015.

[3] Finnegan W, Goggins J. "Linear irregular wave generation in a numerical wave tank". Applied Ocean Research, 52, 188-200, 2015.

[4] Bhinder MA, Babarit A, Gentaz L, Ferrant P. "Potential time domain model with viscous correction and CFD analysis of a generic surging floating wave energy converter". International Journal of Marine Energy, 10, 70-96, 2015.

[5] Yao Y, Chen Y, Zhou H, Yang H. "Numerical modeling of current loads on a net cage considering fluid-structure interaction". Journal of Fluids and Structures, 62, 350-366, 2016.

[6] Liaghat T, Guibault F, Allenbach L, Nennemann B. "Two-way fluid-structure coupling in vibration and damping analysis of an oscillating hydrofoil". ASME International Mechanical Engineering Congress and Exposition Proceedings, Huston, Texas, USA, 1-13, 9-15 November 2015.

[7] Liu Z, Hyun BS, Hong KY. "Application of numerical wave tank to OWC air chamber for wave energy conversion". Proceedings Eighteenth International Offshore and Polar Engineering Conference, Canada, 350-356, July 2008.

[8] Wang BL, Liu H. "Higher order Boussinesq-type equations for water waves on uneven bottom". Applied Mathematics and Mechanics, 26(6), 774-784, 2005.

[9] Zhu Y, Li Y, Tao A, Zhang J. "Numerical modeling of wave interaction with double curtain-wall breakwater". Procedia Engineering, 116(1), 1009-1018, 2015.

[10] Ojieh NC, Barltrop NDP, Xu L. "RANS investigation of the kinematics of an alternative extreme wave". Ocean Engineering, 36(17-18), 1415-1424, 2009.

[11] Liang X, Yang J, Li J, Li X. "A numerical study on local characteristics of predetermined irregular wave trains". Ocean Engineering, 38(4), 651-657, 2011.

[12] McCormick ME. "Ocean engineering wave mechanics". John Wiley \& Sons Inc, 1973.

[13] ANSYS Fluent Theory Guide 15.0. ANSYS, Inc.

[14] Versteeg HK, Malalasekara W. "An introduction to computational fluid dynamics the finite volume method". London: Longman Group, 1995.

[15] Dean RG, Dalrymple RA. Water Wave Mechanics for Engineers and Scientists, 2. World Scientific, 1991.

[16] Liu Z, Hyun B, Jin J. "Numerical analysis of wave field in owc chamber using VOF model". Journal of Ocean Engineering and Technology, 22(2), 1-6, 2008.

[17] Gomes MN, Isoldi LA, Olinto CR, Rocha LAO, Souza JA. "Computational modeling of a regular wave tank". Journal of Thermal Engineering, 8(1), 44-50, 2009.

[18] Gomes MN, Isoldi LA, Olinto CR, Rocha LAO, Souza JA. "Computational modeling of a regular wave tank". Proc. - 2009 3rd South. Conf. Comput. Model. MCSUL, 60-65, 2009. 